\title{
Pendidikan Islam dan
}

\section{Tantangan The Great Shifting di Era Pandemi Covid-19}

\author{
Dewi Maharani', Rizkha Diana Akmalia' ${ }^{2}$, Gita Yuniar Faradilla ${ }^{3}$ \\ ${ }^{1}$ Fakultas Tarbiyah, Institut Ilmu Al-Qur'an Jakarta, Indonesia \\ ${ }^{2}$ Fakultas Tarbiyah, Institut Ilmu Al-Qur'an Jakarta, Indonesia \\ ${ }^{3}$ Fakultas Tarbiyah, Institut Ilmu Al-Qur'an Jakarta, Indonesia \\ 1dewimaharani@iiq.ac.id \\ 2rizka.diana@gmail.com \\ 3yuniar.gita21@gmail.com
}

\section{DOI: 10.37542/iq.v4i01.193}

\begin{abstract}
This article was written to explain the strategic relationship between Islamic Education in facing changes in the Covid-19 pandemic era, how Islamic education, which in quantity shows progress, but in terms of quality is still questionable, it can be seen from the output of Islamic Education Institutions in taking employment opportunities in the country. alone is still far from people's expectations, this problem was exacerbated by the emergence of the Covid-19 pandemic which changed the technology-based education system. This study uses a qualitative approach with descriptive analysis, while the data collection technique is in the form of documentation which is then analyzed. The results of the study show that the strategies carried out in developing Islamic Education in the face of Covid-19: First, Having a Second Morality Commitment, Outcome of Skills and Expertise, Third, Mastering Science, Technology and Innovative Ability, Fourth, Collaborating with stakeholders and foreign institutions.
\end{abstract}

Keywords: Islamic Education, Educational Challenges, Shifting, Covid-19 Pandemic.

\begin{abstract}
Abstrak
Artikel ini ditulis untuk menjelaskan mengenai relasi strategi Pendidikan Islam dalam menghadapi perubahan di era pandemic covid-19, betapa Pendidikan Islam yang secara kuantitas menunjukan perkembangan namun dari sisi kualitas masih dipertanyakan hal tersebut dapat dilihat dari output Lembaga Pendidikan Islam dalam menempuh lapangan kerja di dalam negeri saja masih jauh dari harapan masyarakat, permasalahan ini diperparah dengan
\end{abstract}


munculnya pandemic Covid-19 yang merubah system Pendidikan berbasis teknologi. Penelitian ini menggunakan pendekatan kualitatif dengan analisis deskriptif, adapun teknik pengumpulan datanya berupa dokumentasi yang kemudian dianalisis. hasil penelitian menunjukan bahwa strategi yang dilakukan dalam mengembangkan Pendidikan Islam dalam menghadapi Covid-19: Pertama, Memiliki Komitmen Moralitas Kedua, Outcome Keterampilan dan Keahlian, Ketiga, Menguasai Sains, Teknologi dan Kemampuan Inovatif, Keempat, Bekerjasama dengan stakeholder dan instusi luar Negeri Kelima, Memiliki Akses Pasar Kerja.

Kata Kunci : Pendidikan Islam, Shifting, Pandemi Covid-19. Tantangan Pendidikan

\section{Pendahuluan}

Seiring dengan berkembangnya teknologi informasi, maka fase industri 4.0 akan dimulai, shifting dari industri berbasis orang pada industri berbasis teknologi informasi, program komputer, komunikasi virtual, kecerdasan artifisial, bahkan perubahan gaya hidup, nilai-nilai budaya pada industri 4.0 ini membuat Pendidikan akan mengalami perubahan.

Pandemi Covid-19, membuat semua dosen, guru, mahasiswa dan siswa masuk dalam frame WFH dan menggunakan Teknologi Informasi sebagai tool of work. Tidak hanya itu Pandemi Covid-19 juga mengubah secara revolusioner pembelajaran yang diselenggarakan oleh kampus maupun sekolah. Dalam waktu cepat, sekolah atau kampus dipaksa untuk melaksanakan pembelajaran daring. Ada sekitar 97\% perguruan tinggi telah mengadopsi pembelajaran daring. ${ }^{1}$

Realitas di atas membawa dampak yang luar biasa terhadap pendidikan Islam mulai dari terjadinya penurunan semangat belajar ${ }^{2}$, penurunan capaian pembelajaran ${ }^{3}$, anak kurang bersosialisasi ${ }^{4}$, menjadi korban kekerasan orang tua, ${ }^{5}$ putus sekolah ${ }^{6}$ dan masih banyak lagi

\footnotetext{
${ }^{1}$ Tian Belawati dan Nizam, Potret Pendidikan Tinggi Di Masa Covid-19, (Jakarta: Dirjen Dikti, 2020): 23.

2 Adhetya Cahyani, Iin Diah Listiana, dan Sari Puteri Deta Larasati. "Motivasi Belajar Siswa SMA pada Pembelajaran Daring di Masa Pandemi Covid-19." IQ (Ilmu Al-qur'an): Jurnal Pendidikan Islam 3.01 (2020): 123-140.

3 Baeti Rohman, Jamil Abdul Aziz, dan Jarudin Ali Imran. "Distance Instructional Strategies and Learning Motivation towards Learning Outcome of the Study Al-Qur'an in Situation a COVID-19 Pandemic." Universal Journal of Educational Research 8.12 (2020): 6609-6619.

${ }^{4}$ Dasrun Hidayat, dan Noeraida Noeraida. "Pengalaman Komunikasi Siswa Melakukan Kelas Online Selama Pandemi Covid-19." JIKE: Jurnal Ilmu Komunikasi Efek 3.2 (2020): 172-182.

5 Diana Putri Arini. "Apakah Kekerasan pada Anak Merupakan Bentuk Parental Burnout di Masa Pandemi?." Seminar Nasional Psikologi UM. Vol. 1. No. 1. 2021.

6 Teguh Triwiyanto. "BUKAN SEKEDAR SUBSIDI PULSA, UNTUK MENGURANGI ANGKA PUTUS SEKOLAH DAMPAK PANDEMI COVID-19." Seminar Nasional Arah Manajemen Sekolah Pada Masa Dan Pasca Pandemi Covid-19. 2020.
}

76 | IQ (Ilmu Al-qur'an): Jurnal Pendidikan Islam| Volume 4 No.01 2021, 75-86 
dampak negatif yang akan terjadi. Kondisi ini membuat masyarakat khususnya guru, dosen, mahasiswa diharuskan untuk dapat menyesuaikan shifting yang ada saat ini, fenomena tersebut terbukti dengan melansir data yang dilansir pada akhir Maret, 95\% perguruan tinggi telah melakukan pembelajaran dari rumah. Dari jumlah tersebut 98,2\% melakukan pembelajaran daring, kurang dari $2 \%$ melakukan bentuk pembelajaran lainnya. Sebagian besar mahasiswa $(68,7 \%)$ menggunakan ponsel untuk pembelajaran daring, 14,3\% memakai laptop, 10,7\% desktop, $0,7 \%$ tablet, dan 5,6\% peralatan lainnya. ${ }^{7}$

Pada konteks yang lain sebagaimana survei yang dilakukan Mckinsey Global Institute di 54 negara yang merepresentasikan 78\% dari total tenaga kerja dunia (2017), otomatisasi akan berdampak pada 50\% pekerjaan (328,9 juta pekerja) pada sektor pertanian, kehutanan, dan perikanan, 64\% pekerjaan (237,4 juta pekerja) di sektor manufaktur, dan 54\% pekerjaan (187,4 juta pekerja) di sektor ritel. McKinsey juga memprediksi 23 juta lapangan kerja di Indonesia akan hilang dalam 10 tahun ke depan, sementara 27 hingga 46 juta lapangan kerja baru yang saat ini belum ada berpotensi tercipta. ${ }^{8}$ Berdasarkan data di atas menunjukkan bahwa Indonesia benar-benar membutuhkan layanan Pendidikan tinggi yang relevan dalam menyongsong tantangan zaman dimasa depan. Layanan Pendidikan yang menuntut kita untuk melakukan inovasi baru dalam mengembangkan Pendidikan yang akan menentukan kualitas lulusan.

Melihat kondisi di atas maka shifting yang terjadi saat ini menuntut kita untuk menyongsong dan memperbaiki serta melakukan inovasi baru dalam menyusun strategi Pendidikan Islam yang akan datang.

Dalam konteks pendidikan Islam, sebagai konsekuensinya strategi yang dilakukan tulisan ini secara garis besar memuat 4 gagasan besar yang cukup urgen untuk dikaji secara mendalam, di antaranya adalah; 1) Sketsa Historis Peran Strategis Pendidikan Islam 2) Paradigma The Great Shifting dalam Pendikan Islam 3) Peluang Pendidikan Islam dalam Menghadapi Covid-19 4) Strategi Pendidikan Islam dalam menghadapi Covid-19

Penelitian ini merupakan penelitian kualitatif, penelitian yang dilakukan masuk dalam jenis penelitian kepustakaan (Library Research), di mana seluruh data penelitian dihasilkan berdasarkan literatur yang berkaitan dengan obyek penelitian, dari hasil pemikiran para pakar kemudian penulis Analisa dengan menggunakan analisis deskriptif dan analisis isi. ${ }^{9}$

\footnotetext{
${ }^{7}$ Tian Belawati dan Nizam, Potret Pendidikan Tinggi Di Masa Covid-19, (Jakarta: Dirjen Dikti, 2020):23.

${ }^{8}$ McKinsey, Automation and the future of Work Indnesia, 2019.

${ }^{9}$ Novan Ardy Wijani \& Barnawi, Ilmu Pendidikan Islam, (Jogjakarta: Ar-Ruzz Media, 2012), Cet. ke1,53 .
} 


\section{Pembahasan}

\section{Sketsa Historis Peran Strategis Pendidikan Islam}

Secara historis, Pendidikan Islam memiliki peran membentuk manusia berkualitas yang memiliki rasa tanggung jawab dalam menghadap perkembangan zaman dimasa depan. Hal tersebut sejalan dengan pendapat Syaiful Anwar bahwa Pendidikan Islam sebagai kawah pengembangan intelektualitas memiliki peranan penting dalam mengembalikan kejayaan peradaban dan pendidikan Islam melahirkan kembali sosok-sosok intelektual muslim yang memiliki integritas secara intelektual, moral, dan spiritual, baik melalui komitmen keilmuan maupun komitmen kebangsaannya. ${ }^{10}$ Berbeda dengan Ramayulis ${ }^{11}$ yang membagi Peran Pendidikan Islam menjadi 2 Peran di antaranya: Pertama, Pendidikan Islam sebagai Mata Pelajaran a) Mempercepat proses pencapaian Tujuan Pendidikan Nasional, Pendidikan Nasional bertujuan untuk berkembangnya potensi peserta didik agar menjadi manusia yang beriman kepada Tuhan Yang Maha Esa, berakhlak mulia, sehat, berilmu, cakap, kreatif mandiri, dan menjadi warga negara yang demokratis serta bertanggung jawab. Secara sederhana dapat dirinci poin-poin yang terdapat dalam tujuan Nasional tersbut 1. Berkembangnya potensi peserta dididik 2. Beriman dan bertakwa kepada Tuhan yang Maha Esa 3. Berakhlak mulia, sehat, berilmu, cakap, kreatif dan mandiri, 4. Menjadi warga negara yang demokratis 5. Bertanggung jawab. b) Memberikan nilai terhadap mata pelajaran umum Kedua, Pendidikan Islam sebagai Lembaga (Institusi) a) Lembaga Pendidikan Islam (Pondok Pesantren) berperan mencerdaskan kehidupan bangsa. Keberadaan pesantren ada semenjak masuknya Islam ke Indonesia mulai dari masa kolonial Belanda hingga saat ini. Apalagi pesantren bersifat populis yang banyak diminati oleh masyarakat, b) Lembaga Pendidikan (Madrasah dan Pesantren) madrasah merupakan metamorposis dari pesantren yang hendak bertransformasi untuk bisa diterima pasar kerja di pemerintahan Hindia Belanda. Dan dari perusahaan Belanda, pada Lembaga ini diberlakukan menuntaskan pelaksanaan wajib belajar 9 tahun, c) Lembaga Pendidikan Islam (Madrasah Diniyah) berperan mendidik anak-anak yang dropouot, anak-anak yang tidak berkesempatan memasuki Lembaga Pendidikan formal karena keterbatasan jam pelajaran di sekolah, maka peserta didik dapat memperluas dan memperdalam mata pelajaran ini di madrasah Diniyah (MDA, MDW dan MDU).

Dari pendapat di atas maka penulis tegaskan bahwa betapa besarnya peran pendidikan Islam dalam upaya mencerdaskan bangsa, terlepas dari kelemahan yang ada saat ini. Oleh

\footnotetext{
${ }^{10}$ Syaiful Anwar, "Peran Pendidikan Agama Islam dalam Membentuk Karakter Bangsa", Al Tadzkiyyah: Jurnal Pendidikan Islam, Vol. 7 No. 2 (2016), 7

${ }^{11}$ Ramayulis, Ilmu Pendidikan Islam, (Jkarta: Klaam Mulia, 20), 44-45.
} 
karena itu sudah menjadi kewajiban Pendidikan Islam di Indonesia khususnya dengan melihat historisitas peran strategis yang telah lakukan untuk kemajuan bangsa dan negara ini, maka perlu dilakukan perbaikan secara terus menerus untuk menjadi lebih baik karena tanpa adanya dukungan dari berbagai pihak maka tidak mungkin Pendidikan Islam dapat melanjutkan kiprah strategisnya dimasa-masa yang penuh dengan perubahan zaman ini.

\section{Paradigma The Great Shifting dalam Pendidikan Islam}

Berdasarkan pendapat Renaldi Kasali pengertian dari great shifting di sini perpindahan abadi yang menentukan apakah kita bisa bertahan atau tidak. Berubah atau punah. Dalam pandangan tersebut perubahan yang terjadi pada perilaku masyarakat adalah akibat dari teknologi informasi, percepatan teknologi yang terjadi saat ini hingga sampai tahun 2030 sekitar 2 milyar pegawai di seluruh dunia akan kehilangan pekerjaan. Tak mengherankan bila mulai banyak anak-anak yang bertanya dengan polos terhadap orang tuanya terkait pekerjaannya yang akan datang. ${ }^{12}$

Berikut poin-poin Shifting memasuki fase disrupsi yang dirumuskan Renaldi Kasali dalam bukunya : (1) Shifting Product Platform (2) Shifting Forom Competition (3) Shifting from rill bussinness (4) Shifting dari orientasi bisnis kota (5) Shifting dari industri padat karya. 13

Merujuk pada teori yang diusung Renaldi Kasali di atas, jika dikaitkan dengan Pendidikan dan fenomena covid-19 maka dapat penulis analisis sebagai berikut :

\section{The Great Shifting Tenaga pendidik dalam memanfaatkan Teknologi Informasi Sebagai Tool Work}

Melihat fenomena yang terjadi saat ini, covid-19 telah mengubuh tatanan kehidupan kita menjadi lebih praktis dan inovatif, hal tersebut terbukti dengan adanya dosen, guru, mahasiswa dan siswa telah mengubah proses pembelajaran dengan menggunakan Teknologi Informasi seperti melakukan kegiatan belajar mengajar dengan aplikasi Zoom, google meet, atau paling tidak menggunakan Whatsapp Group sebagai tool of teaching and learning.

Berdasarkan analisis penulis di atas hal tersebut sejalan dengan pendapat Budiana, Syafira dkk, bahwa kemampuan TIK yang luar biasa seharusnya dimanfaatkan dalam dunia

\footnotetext{
pada 3 Maret 2021

13 Renaldi Kasali, The Great Shifting, (Jakarta: PT. Gramedia Pustaka Utama, 2018) 37-38.
} 
pendidikan dalam rangka melahirkan sistem pendidikan yang lebih baik, baik dalam aspek sarana prasarana, peningkatan profesionalisme kualitas sumber daya manusia pendidik (guru) maupun menghasilkan anak didik yang berkualitas. ${ }^{14}$

\section{The Great Shifting Konten Web sebagai Sumber Belajar}

Dalam membantu proses pembelajaran guru dan dosen tidak cukup dengan memanfaatkan teknologi di atas, namun salah satu upaya yang dilakukan adalah dengan menggunakan konten-konten web sebagai sumber belajar, selain sebagai sumber belajar web juga dapat digunakan untuk menyimpan bahan ajar yang mudah diakses oleh mahasiswa dan siswa dalam hal ini sejalan dengan apa yang dikatakan oleh Tim Penelitian dan Pengembangan Wahana Komputer dalam tulisan Agus Swasono. ${ }^{15}$ menjelaskan bahwa website adalah sebuah tempat dalam World Wide Web di mana homepage sebuah organisasi atau individual berada. Sebuah situs web (website) biasanya ditempatkan setidaknya pada sebuah server web yang dapat diakses melalui jaringan seperti internet, ataupun jaringan wilayah lokal/Local Area Network (LAN) melalui alamat internet yang dikenali sebagai Uniform Resource Locator (URL).

Selain pemanfaatan yang dihasilkan dari teknologi informasi, pada aspek yang lain teknologi informasi juga menjadi pesaing baru bagi guru dan dosen, karena ke depan mahasiswa dan siswa akan berkurang ketergantunganya pada guru dan dosen, karena melihat perubahan yang terjadi dengan berkembangnya teknologi informasi maka sekolah dapat dilakukan di mana saja, kapan saja dan dengan siapa saja, meskipun pada hakikatnya guru tidak akan dapat digantikan oleh teknologi informasi, namun kita harus tetap berupaya mengikuti zaman tanpa menghilangkan nilai-nilai moralitas sebagai dasar yang ada dalam agama Islam.

\section{Membagun Networking dengan banyak Mitra di Dunia}

Bersdasarkan hemat penulis salah satu kelemahan Pendidikan di Indonesia khusunya Pendidikan Islam adalah enggan untuk berkompetisi pada taraf nasional maupun internasional hal tersebut dapat dilihat dari laporan data Education Index yang dikeluarkan oleh Human Development Reports, pada 2017, Indonesia ada di posisi ketujuh di ASEAN

\footnotetext{
${ }^{14}$ Budiana dkk, Pemanfaatan teknologi informasi dan komunikasi dalam pembelajara..., Jurnal Aplikasi Iptek s untuk Masyarat, vol. 4, No. 1 (Mei 2015).

15 Agus Swasono, "Pengembangan Media Pembelajaran IPS Berbasis Website" Skipsi: Universitas Negeri Yogyakarta, 2013.
}

80 | IQ (Ilmu Al-qur'an): Jurnal Pendidikan Islam| Volume 4 No.01 2021, 75-86 
dengan skor 0,622. Skor tertinggi diraih Singapura, yaitu sebesar 0,832. Peringkat kedua ditempati oleh Malaysia $(0,719)$ dan disusul oleh Brunei Darussalam $(0,704)$. Pada posisi keempat ada Thailand dan Filipina, keduanya sama-sama memiliki skor 0,661. ${ }^{16}$

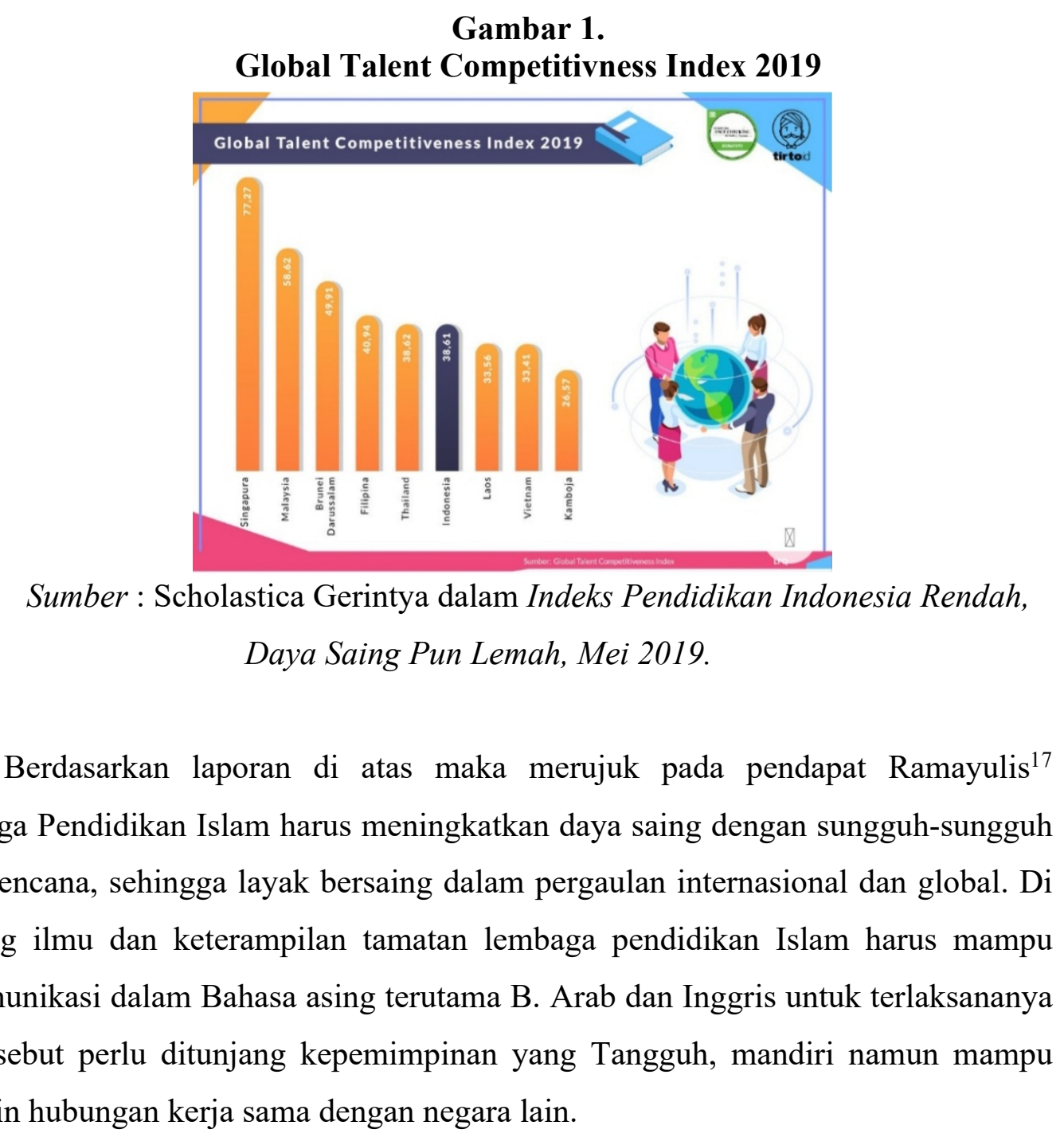
menjalin hubungan kerja sama dengan negara lain.

\section{Peluang Pendidikan Islam dalam Menghadapi Covid-19}

Dalam menyikapi perubahan yang terjadi pada Pendidikan Islam saat ini, tentu tak terlepas dari hikmah atau peluang dari apa yang melanda dunia di era pandemi covid-19 ini, oleh karena itu berikut peluang Pendidikan Islam dalam menghadapi Covid-19 : Pertama, Hampir seluruh guru dan dosen memanfaatkan teknologi informasi, walaupun sebelumnya hampir seluruh E-Learning yang tersedia dilembaga Pendidikan pada masing-masing kampus tidak pernah digunakan oleh guru, dosen mahasiswi dan siswa. Kedua, hampir seluruh

\footnotetext{
${ }^{16}$ Scholastica Gerintya dalam Indeks Pendidikan Indonesia Rendah, Daya Saing Pun Lemah, Mei 2019. https://tirto.id/dnvR. Diakses 7 Maret 2021

${ }^{17}$ Ramayulis, Ilmu Pendidikan Islam, (Jkarta: Klaam Mulia, 20), 351.
} 
kalangan masyarakat mengetahui bahwa internet itu luar biasa dahsyat dan bahkan internet itu lebih besar hasilnya dari pada phisical meeting, Ketiga, dengan covid-19, Kualitas Guru dan dosen akan semakin meningkat.

\section{Strategi Pengembangan Pendidikan Islam dalam Menghadapi Covid-19}

Ketika globalisasi dihadapkan dengan pendidikan Islam, maka muncul dua implikasi sekaligus, yakni peluang dan ancaman. Sebagai peluang, globalisasi di satu sisi akan memudahkan Pendidikan Islam untuk mengakses berbagai informasi secara cepat, juga memudahkan pendidikan Islam untuk menyebarluaskan produk-produk keilmuan yang memberikan manfaat bagi masyarakat. Selanjutnya sebagai ancaman, ternyata globalisasi tidak hanya mempengaruhi tatanan kehidupan pada tataran makro, tetapi juga mengubah tata kehidupan pada level mikro, yaitu terhadap ikatan kehidupan sosial masyarakat. Globalisasi memicu fenomena disintegrasi sosial, hilang nilai-nilai tradisi, adat-istiadat, sopan santun, dan penyimpangan sosial lainya. ${ }^{18}$

Menyikapi pendapat di atas, maka sebagai jalan tengah salah satu upaya yang dilakukan dalam mewujudkan keberhasilan dan memperbaiki kualitas pendidikan pada masa pandemi covid-19 ini, maka Pendidikan Islam harus memiliki strategi dalam pengembangannya. Hal tersebut diharapkan agar Pendidikan Islam mampu berkembang dan maju sesuai dengan kebutuhan masyarakat global tanpa harus mengorbankan salah satu pihak.

Dalam konteks tersebut, maka penulis uraikan beberapa strategi sebagai salah satu alternative dalam pengembangan Pendidikan dalam menghadapi Shifting di era pandemic Covid-19 yang diantaranya sebagai berikut: ${ }^{19}$

\section{Memiliki Komitmen Moralitas}

Berdasarkan hemat penulis menyikapi perubahan yang terjadi adalah dengan memodernisasi tentang pemahaman kita terhadap ajaran-ajaran agama yang belum sesuai dengan kemajuan zaman dalam arti pemahaman keagamaan kita harus mampu mendorong kita untuk menciptakan sesuatu yang baru, dalam hal ini kita dituntut untuk kreatif dan inovatif. Agama Islam sebagai dasar dalam menyongsong perkembangan teknologi informasi tentunya dengan tidak menghilangkan standar nilai akhlak sebagai muslim yang

${ }^{18}$ Zubaedi, 2020. 54.

${ }^{19}$ Ramayulis, Ilmu Pendidikan Islam, (Jakarta: PT. Kalam Mulia, 2002), 352-354. 
baik, karena akhlak menjadi standar nilai yaitu standar kemuliaan di tengah hidup yang serba berubah dalam hal ini. ${ }^{20}$

\section{Outcome Keterampilan dan Keahlian}

Sumber Daya Manusia (SDM) merupakan kunci utama, oleh karena itu harus dipersiapkan skill dan keahlian, karena mereka akan banyak kehilangan kesempatan untuk masuk dalam industri manufaktur : a) Madrasah pada tingkat MTS dan MA, sudah Islami, namun belum ada keterampilan, khususnya ketrampilan dalam mengembangkan teknologi. b) Pada tingkat PT, masih banyak ditemukan IAIN, dan itu tidak Islami, karena menganggap Islam itu hanya akidah dan syari'ah. Padahal jika merujuk pada QS. AlMujadalah ayat 11, menegaskan bahwa Islam itu holistik c) Mulailah ambil keterampilan bagi yang berada pada program studi murni, mengambil sks bersertifikat yang bisa akses pada pasar kerja. harus ambil keahlian yang memiliki market share, dan hitung dalam transkrip nilai. e)mengambil hikmah dari covid-19 bahwa mereka yang memiliki kreativitas, siapa yang kreatif, adalah mereka yang memiliki basis keterampilan yang menjual.

\section{Menguasai Sains, Teknologi dan Kemampuan Inovatif}

Mengutip pendapat Mawardi dalam tulisannya bahwa mengambil sisi positif dari pengembangan ilmu pengetahuan Berdasarkan Kemajuan Ilmu Pengetahuan dan Teknologi, merupakan salah satu strategi dalam menghadapi perubahan globalisasi karena Pendidikan Islam saat ini sedang ditantang kontribusinya terhadap pembentukan peradaban dan budaya modern yang relevan dengan perkembangan ilmu pengetahuan, teknologi, dan seni (Ipteks). Pada dimensi ini, pendidikan Islam mengalami kemunduran fungsi (degradasi fungsional) karena pendidikan Islam lebih berorientasi pada aspek moral spiritual. Memodernisasikan metodologi Pendidikan dan pengajaran dalam menguasai pengetahuan teknologi perlu metodologi, sepeti Pendidikan dan pengajaran diperlukan modernisasikan metodologi Pendidikan dan pengajaran di sekolah-sekolah Islam ${ }^{21}$

Dari pendapat di atas maka dapat ditarik kesimpulan bahwa Pendidikan Islam perlu memasukkan produk dari teknologi atau Pendidikan berbasis teknologi multimedia atau

\footnotetext{
${ }^{20}$ Nursheha Qosim Dzulhadi, "Islam sebagai Agama dan Peradaban”, Jurnal TSAQAFAH Vol 11 No 1 (2015). Ramayulis, Ilmu Pendidikan Islam, Jakarta: Kalam Mulia, 2002. DOI: http://dx.doi.org/10.21111/tsaqafah.v11i1.258

${ }^{21}$ Mawardi, Tantangan Pendidikan di Era Globalisasi, dalam Jurnal Tarbawi| Volume 1|No 1| ISSN 25274082
} 
Dewi Maharani, Rizkha Diana Akmalia, Gita Yuniar Faradilla

saintifikasi Pendidikan. Jangan sampai Lembaga madrasah atau perguruan tinggi kita ketinggalan karena alasan tidak memiliki internet, tidak berbasis E learning dan Mobile learning.

\section{Bekerjasama dengan stakeholder dan institusi luar Negeri}

Untuk pengembangan kajian Islam perlu memerlukan korporat atau perguruan tinggi yang bekerja sama dengan stakeholder atau dengan Lembaga-lembaga dan instansi lain sehingga lulusan Perguruan tinggi Agam Islam tidak terasing dengan dunia luar dan bisa tersalurkan, bisa terserap dengan dunia kerja, tidak hanya itu Lembaga Pendidikan Islam harus melakukan akuntabilitas, akuntabilitas tidak hanya dalam hal pemanfaatan sumbersumber keuangan secara lebih bertanggungjawab tetapi juga dalam pengembangan keilmuan, kandungan Pendidikan dan program-program yang diselenggarakan. ${ }^{22}$

\section{Kesimpulan}

Covid-19 merupakan realitas kekinian yang telah mengubah seluruh tatanan kehidupan khususnya dalam dunia Pendidikan, namun untuk mempertahankan kualitas pendidikan Islam harus menyiapkan strategis yang tepat dalam mempertahankan identitasnya sehingga sistem Pendidikan Islam tidak hanya mampu berkompetisi dengan dunia luar tetapi tanpa kehilangan Islamic Moralitaty. Asumsi itu setidaknya harus didukung oleh strategi pengembangan Pendidikan Islam yang lebih baik; Pertama, Memiliki Komitmen Moralitas Kedua, Outcome Keterampilan dan Keahlian, Ketiga, Menguasai Sains, Teknologi dan Kemampuan Inovatif, Keempat, Bekerja sama dengan stakeholder dan institusi luar Negeri.

\section{Daftar Pustaka}

Arini, Diana Putri. "Apakah Kekerasan pada Anak Merupakan Bentuk Parental Burnout di Masa Pandemi?." Seminar Nasional Psikologi UM. Vol. 1. No. 1. 2021.

Belawati, Tian dan Nizam, Potret Pendidikan Tinggi Di Masa Covid-19, (Jakarta: Dirjen Dikti, 2020.

Budiana H.R., Sjafirah N.A DKK, "PEMANFAATAN TEKNOLOGI INFORMASI DAN KOMUNIKASI DALAM PEMBELAJARAN BAGI PARA GURU SMPN 2 KAWALI DESA CITEUREUP KABUPATEN CIAMIS" Jurnal Dharmakarya: Aplikasi Iptek Untuk Masyarakat, Vol. 4, No. 1, (Mei 2015).

${ }^{22}$ Ramayulis, Ilmu Pendidikan Islam, (Jakarta: PT. Kalam Mulia, 2002), 351-35 
Cahyani, Adhetya, Iin Diah Listiana, dan Sari Puteri Deta Larasati. "Motivasi Belajar Siswa SMA pada Pembelajaran Daring di Masa Pandemi Covid-19." IQ (Ilmu Al-qur'an): Jurnal Pendidikan Islam, Vol. 3 No. 01 (2020): 123-140.

Dzulhadi, Nursheha Qosim, "Islam sebagai Agama dan Peradaban”, Jurnal TSAQAFAH Vol 11 No 1 (2015).

Gerintya, Scholastica, Indeks Pendidikan Indonesia Rendah, Daya Saing Pun Lemah, https://tirto.id/dnvR. Diakses 7 Maret 2021.

Hidayat, Dasrun, dan Noeraida Noeraida. "Pengalaman Komunikasi Siswa Melakukan Kelas Online Selama Pandemi Covid-19." JIKE: Jurnal Ilmu Komunikasi Efek 3.2 (2020): 172-182.

Kasali, Renaldi, The Great Shifting, Jakarta: PT. Gramedia Pustaka Utama, 2018.

Kinsey, Mc, “Automation and the future of Work Indnesia”, New Left Review (2019).

Ramayulis, Ilmu Pendidikan Islam, Jakarta: Kalam Mulia, 2002. DOI: http://dx.doi.org/10.21111/tsaqafah.v11i1.258

Rohman, Baeti, Jamil Abdul Aziz, dan Jarudin Ali Imran. "Distance Instructional Strategies and Learning Motivation towards Learning Outcome of the Study Al-Qur'an in Situation a COVID-19 Pandemic." Universal Journal of Educational Research 8.12 (2020): 6609-6619.

Swasono, Agus, "Pengembangan Media Pembelajaran IPS Berbasis Website" Skipsi: Universitas Negeri Yogyakarta, 2013.

Triwiyanto, Teguh. "BUKAN SEKEDAR SUBSIDI PULSA, UNTUK MENGURANGI ANGKA PUTUS SEKOLAH DAMPAK PANDEMI COVID-19." Seminar Nasional Arah Manajemen Sekolah Pada Masa Dan Pasca Pandemi Covid-19. 2020.

Wijani, Ardi Novan \& Barnawi. Ilmu Pendidikan Islam, Cet. ke-1. Jogjakarta: Ar-Ruzz Media, 2012. 
Dewi Maharani, Rizkha Diana Akmalia, Gita Yuniar Faradilla

86 | IQ (Ilmu Al-qur'an): Jurnal Pendidikan Islam | Volume 4 No.01 2021, 75-86 